\title{
Polyploid rootstocks in citrus for mitigation of biotic and abiotic stresses: A review
}

\author{
JS Gora, Chet ram, PK Poonia, M Choudhary \& SM Haldhar
}

Journal of Agriculture and Ecology

ISSN: 2456-9410

Volume: 13

Journal of Agriculture and Ecology (2022) 13: 1-19 http://doi.org/10.53911/JAE.2022.13101

\section{Journal of}

\section{Agriculture and}




\section{Polyploid rootstocks in citrus for mitigation of biotic and abiotic stresses: A review}

$\mathrm{JS}_{\text {Gora }}{ }^{1} \varnothing$, Chet Ram ${ }^{1}$, PK Poonia ${ }^{1}$, M Choudhary $^{1} \&$ SM Haldhar ${ }^{2}$

${ }^{1}$ ICAR-Central Institute for Arid Horticulture, Beechwal, 334006, India

${ }^{2}$ Department of Entomology, COA, CAU, Imphal-795004

$\triangle$ Corresponding author: JS Gora, E-mail: jagangora@gmail.com

\section{Article Info}

Article history

Received: 01 January 2022

Accepted: 15 January 2022

Available online: 30 January 2022

Key Words: Citrus, polyploidy, root stocks, salinity, drought, HLB, Tristeza, tolerance.

\begin{abstract}
Citrus is growing commercially worldwide for its nutritious value and economical aspects. By 2030, citrus fruit demand will be more around 50 percent as human diet. However, the environmental stresses are badly affected citrus production and productivity as well as fruit quality. These factors are reduced citrus production by 30-60 per cent in traditional citrus growing area in the world due to the lack of suitable rootstocks. The polyploidy rootstocks can play pivotal role to mitigate the environmental impacts and sustainability in citriculture for vigor and fruit quality. Polyploid citrus rootstocks have great importance in crop improvement programmes due to their attributes to the higher vigor, dwarfism, resistant to biotic and abiotic stresses when compared to their diploid counterparts. They exhibit deep and thick root system with less number of secondary roots, more ABA synthesis, leathery and thick leaves, bigger sized stomata with less density, high antioxidant system etc. In the present paper, an attempt has been made to elucidate and discuss the importance of polyploidy rootstocks developed so far for various horticultural traits in citrus.
\end{abstract}

Copyright (C2022 Gora et al., This is an open access article published under the terms of the Creative Commons Attribution License, which permits unrestricted use, distribution, and reproduction in any medium, provided the original work is properly cited.

Preferred citation: Gora JS, Chet Ram, Poonia PK, Choudhary M \& Haldhar SM. 2022. Polyploid rootstocks in citrus for mitigation of biotic and abiotic stresses: A review. Journal of Agriculture and Ecology, 13: 1-19; http://doi.org/10.53911/JAE.2022.13101

\section{Introduction}

Citrus is an important fruit crop worldwide. The global production of citrus is 121.27 MT (FAO 2015). It is mainly grown in China, Brazil, USA, Spain, Mexico, India and Argentina. The genus citrus includes more than 162 species belonging to the order Geraniales of Rutaceae family and sub family Aurantoideae (Webber \& Batchelor 1948;
Scora 1975). Citrus fruits have long been used as nutritious and tasty diet. The citrus flavors are most preferred bio-compound in the world. It is well-known that citrus is rich source of vitamins, minerals and dietary fibre which are essential for growth and development, overall nutritional fulfillment and to reduce the risk of many chronic diseases of human (Economos 
\& Clay 1998). It is expected that demand for citrus fruits would increase by 50 per cent with increasing of the population and nutritionally of fruits by 2030 (CCRI 2015). Citrus cultivation is facing decline in productivity and quality of fruits caused by various biotic and abiotic factors from centuries. Climate change, pests and diseases are few natural and biological threats which affect the vitality of citrus production in the world. So far, the greatest abiotic problems, that citrus growers facing, are drought, salt, temperature stress and nutrients deficiency. Also, the world citrus industry encounters by viral diseases such as tristeza, exocortis, xyloporosis etc. and bacterial disease like citrus greening or Huanglongbing (Zekri \& Rouse 2016; Gora et al. 2021). Combinedly, all these factors are responsible for citrus decline. Citrus rootstocks is influenced the plant canopy, fruit yield, quality and antioxidant values of the scion cultivars as well as promote the high density planting due to it's their dwarfing nature (Gora et al. 2019; Gora et al. 2022)

The water deficit condition is the main environmental factor that directly affects the growth and yield of citrus (Perez-Perez et al. 2009). The drought condition is directly coping with more salt accumulation in the soil surface due to higher evaporation (AcostaMotos et al. 2017). Salinity also affects the production and productivity of citrus. It adversely affect the osmotic potential, stomatal conductance, $\mathrm{Co}_{2}$ availability, nutritional balance and metabolism of the citrus plants by accumulating toxic ions (Byrt et al. 2018) which leads to reduction in plant growth and fruit yield (Storey \& Walker 1998; Flexas et al. 2007).

Among the biotic factors, citrus tristeza virus (CTV) is one of the biggest oppressions to the citrus industry globally and also a major contributor to citrus decline throughout the world. With the first outbreaks of CTV in South America in the 1940s, it has killed more than 100 million trees worldwide (Bar-Joseph and Dawson 2008) and at recent times, there are more than 400 million citrus trees grafted on sour orange rootstocks at the risk to CTV decline (Moreno \& Garnsey 2010). In Spanish and Portuguese, tristeza, which indicates sadness, was used to describe the quick and widely spread death and decline of millions of citrus trees in Argentina and Brazil on sour orange rootstocks since the 1930s (RochaPena et al. 1995). In India, various researchers also reported that tristeza destroyed about a million citrus trees ranging from 10 to $60 \%$ (Ahlawat 1997; Biswas et al. 2014). The high CTV titre was observed in Kagzilime ( $C$. aurantifolia) and sweet orange (C. sinensis) but it was low in mandarin (C. reticulata) (Biswas et al. 2014). Besides the CTV, citrus orchards are also severely affected by ring spot virus infection. Up to hundred per cent incidence of ring spot disease was reported in the Kinnow mandarin trees in North India, especially in Punjab which reduces fruit yield from 20.54 to 98.38 per cent (Byadgi \& Ahlawat 1995).

Citrus greening disease (HLB) was reported first time in China during 1890's (Lin 1956; Graca 1991). Thereafter, it was spread throughout the world rapidly (Frank 1998) and reducing yield from 10-46 percent in India (Ghosh et al. 2018; Lakshmi et al. 2014) and 
up to 60 per cent in USA (USDA 2014). HLB is caused by the bacteria Candidatus liberibacter spp. which is vectored by Diaphorina citri (Psylla). This disease is apparently responsible for the dieback and death of trees quickly. The HLB leads to a very strong synthesis of starch and callose which obstruct the pores existing between cells (Koh et al. 2012). Thus, it limits the symplastic transport of the carbohydrate synthesized in the leaves to the other organs. The accumulation of carbohydrate in the leaves also related to boron deficiencies (Kim et al. 2009). These consequences are apparently confirmed by Fan et al. (2013) and Johndon et al. (2014) which draw attention of the importance of root system and hence requirement of rootstocks for the tolerance behavior of infected trees. At present, the tolerant source against HLB in citrus is very limited. However, Tahiti lime (natural triploid variety) is showed much less incidence of the disease (Gomez 2008) as compared to other very sensitive varieties of diploid lime. Similarly, some triploid varieties and tetraploid rootstocks have been shown to limit the development of the disease (Grosser \& Gmitter 2013). Furthermore, it has been shown that the adaptation of citrus plants to other abiotic and biotic constraints to ensure proper physiological functioning of the tree in their environment was an important component of the response to HLB (Grosser \& Gmitter 2013).

The production of genetically uniform rootstock is an important task. The potential applications of polyploidy to achieve improved citrus varieties and their uses in crop improvement and genetic manipulations have been realized (Lee 1989). Polyploids such as triploids, tetraploids, hexaploids and octaploids are found spontaneously in citrus. Triploid plants have thick round leaves and show more vigor than tetraploids (Usman et al. 2006). Thus they can be used against biotic and abiotic stresses (Shokrollah et al. 2011), greening disease and salt stress conditions (Podda et al. 2013). In polyploidy, a normally diploid cell or organism acquires one or more additional sets of chromosomes (Soltis \& Soltis 2009). This ubiquitous phenomenon contributes in evolution and diversification of the plants. Using transition based model, Otto and Whitton (2000) suggested that polyploidization occurs in approximately 2-4 per cent of speciation (sympatric) events in angiosperms and 7.0 per cent in ferns. The notable advances in genomic studies have revealed prehistoric cases of polyploidy in plants. Using phylogenetic analysis of expressed sequence tags (EST), Jiao et al. (2011) identified two events of whole genome duplication (WGD), which arise around 319 and 192 million years ago, shortly before the diversification of extant seed plants and flowering plants, respectively. These studies have provided a wide range of information about causes and consequences of polyploidy and different aspects of polyploidy including classification, frequency, mechanism of origin and ancient polyploidy events as well as its ecological, genetic and evolutionary consequences (Soltis \& Soltis 2009; Otto \& Whitton 2000; Osborn et al. 2003; Ramsey \& Ramsey 2014). The diploid rootstocks have prominent effect on growth, productivity and fruit quality but making them susceptible to various insect-pest and diseases. However, 
polyploidization events often seem to be associated with increase in vigor and adaptation of the newly formed plant to novel conditions. A large number of plant species have a polyploid genome. It has attracted the attention of plant breeders for inducing the polyploidy in crop plants as a tool for crop improvement. In citrus, numerous polyploid rootstocks have been utilized for mitigating various biotic and abiotic stresses and for quality improvement of the fruit (Balal et al. 2017; Oustric et al. 2018). However, the comprehensive reports in these contexts are very limited. Therefore, in the present review, we have described the status and importance of the polyploid rootstocks utilized for citrus crop improvement.

\section{Polyploidy}

On the basis of their chromosomal composition, polyploids are classified into two major groups i.e., euploids and aneuploids. Euploids are the polyploids which bear multiples of the complete set of chromosomes specific to a species. The majority of polyploids come under euploidy. On the basis of the composition of the genome, euploids can be further classified into either autopolyploids or allopolyploids. Tetraploidy is one of the most common classes of euploids (Comai 2005). The autoploids contain multiple copies of the basic set (x) of chromosomes of the same genome (Chen 2010). Autoploids occur in nature through union of unreduced gametes and it can also be induced artificially (Chen 2010). The presence of more than two homologous chromosomes in autopolyploids may contribute to the formation of multivalent during meiosis. Due to non-preferential pairing, the off-springs of a cross between two autopolyploids exhibit a different ratio from that of the classical Mendelian cross (1:2:1) and may characterizing as polysomic inheritance (Tayale \& Parisod 2013).

Allopolyploidy is another form of polyploidy having more than the usual number of chromosomes that resulted from the inter-specific hybridization. The allopolyploids are usually infertile with members of their parent species, because the crosses between diploid and tetraploid produce sterile triploid progeny. If the triploid is viable, it is infertile due to some chromosomes being inherited twice, others once, leading to a lack of gene dosage balance in the gametes (Aleza et al. 2010).

\section{Spontaneous polyploidy}

Naturally occurring polyploidy is common in citrus but frequencies are very low (Aleza et al. 2010). It is varying from 13\% (crosspollination) to $73 \%$ (self-pollination) in various varieties and species of citrus (Frost \& Soost 1968). The spontaneously occurred polyploids in citrus are triploids, tetraploids, pentaploids, hexaploids and octaploids. On the basis of type of pollination, polyembryony in citrus can be highly variable even on one tree. This attribute is due to many factors such as rootstock, surrounding environment and plant age (Carvalho \& Silva 2013). Guerra et al. (2016) reported that out of 415 citrus plants, 408 (98.31\%) diploid and seven (1.69\%) tetraploid were found under field condition. Whereas, 406 (93.33\%) diploid and 29 $(6.67 \%)$ tetraploid were found from greenhouse grown 435 citrus plants.

Hybrid origin of genotypes can favor the polyploidization (Machado et al. 2015; Guerra 
et al. 2016). As reported by Carvalho \& Silva (2013), Citrumelo expressed the highest per cent of polyembryony (18.8\%), followed by Rangpur lime and Volkamer lemon (13.7\%), Sunki mandarin $(9.4 \%)$ and Trifoliate orange (3.2\%). The ploidy levels of various Citrus spp. were reported by Usman et al. (2006). Maximum percentage of diploid plants was found in cv. Feutrell's Early (90\%) followed by Mosambi (88\%), Kinnow Mandarin (84\%) and Foster $(82 \%)$ whereas; the $75 \%$ of diploid seedlings were recorded in lime cv. Kagzi. However, the maximum percentage of naturally occurring triploids was found in Kagzi lime (15.45\%), followed by Foster (14\%), Kinnow mandarin (11.33\%) and Mosambi $(9.33 \%)$ and the lowest percentage (7.33\%) of triploid plants was observed in cv. Feutrell's Early (Usman et al. 2006). Similarly, the naturally occurring tetraploid seedlings were recorded in lime cv. Kagzi (9.09\%), Kinnow (4.6\%), Foster (4.0\%), Mosambi (2.66\%) and Feutrell's Early (2\%) (Usman et al. 2006). It was reported that the number of developed and un-developed seeds vary to per fruit per cultivar (Usman et al. 2006). Seeds from open pollinated fruits are polyembryonic in nature with varying number of embryos per seed. The small seeds of polyploids were reported $1 / 3$ to $1 / 6$ proportionally to the diploids seeds size (Soost \& Cameron 1975). Similarly the considerable number of shriveled seeds was also recorded in citrus fruits (Cameron \& Burnett 1978). The seedless condition was reported less frequently in spontaneously developed polyploids (Oiyama \& Kobayashi 1990), while a lower set of fully developed seeds is a common feature of citrus (Oiyama et al.
1981). Less seeded and few fully developed seeds were obtained among spontaneous polyploids by Oiyama \& Kobayashi (1990). The reduced seed size of un-developed seeds might be the result of intrinsic capability of the ovule due to polyploidy and delayed pollination which leading to the shortage or absence of endosperm required for the growth and development of cotyledons. Differences in the frequencies of polyploidy in plants might also be ascribed to certain external factors like temperature, light intensity, etc. (Barret \& Hutchinson 1978). The location of plant and position of the fruit on the plant did not show any significant impact on seed number and its development in citrus (Usman et al. 2006).

\section{Artificial induced polyploidy}

The majority of Citrus spp. is diploid in nature with somatic chromosome number 18 (Soltis \& Soltis 2009). Induced polyploidy is typically carried out in vitro through the use of antimitotic agents. Several chemicals were used to induce polyploidy in plants, however, colchicine, oryzalin and trifluralin are most common. Among them, colchicine is widely used for induction of polyploidy in plants including citrus. The concentration and duration of treatment is varying plant to plant. Germination inhibition caused by colchicine treatment may be due to its toxic effect. This toxicity is proportional to the concentration and exposure duration of the colchicine (Grosser et al. (2014). Zeng et al. (2006) reported that colchicine decreased protoplast viability, delayed protoplast division and inhibited callus growth in kumquat and navel orange. As reported by Abou-Elyazid \& ElShereif (2014), the polyploidy can be induced in $C$. reticulata Balady by the application of 
colchicine at the rate of $0.1 \%$ for $48 \mathrm{~h}$. In Pummelo ( $C$. grandis Osbeck), tetraploids can be produced by applying of $0.05 \%$ and $0.1 \%$ colchicine (Grosser et al. 2014). Tissue wise, the autotetraploid in Pummelo can be induced by treating of germinating seed with colchicine (Kainth \& Grosser 2010). Similarly, the autotetraploid can also be induced in diploid monoembryonic citrus cultivars viz. Clementine, Hassaku and Hyuganatsu by treating of isolated small young axillary buds with $0.1 \%$ colchicine solution for 2-6 h (Oiyama \& Okudai (1986). In addition to this, the tetraploid citrus cultivars can also be produced by top grafting of shoots with colchicine treated sprouting axillary buds (Wakana et al. 2005).

\section{Identification of polyploidy individuals}

The methods for identification of polyploidy individuals are classified as direct and indirect. The indirect methods involve the examination of physiological and morphological traits, especially those related with stomata. In comparison to diploid relatives, polyploid plants usually display larger stomata with lower density and higher number of chloroplasts per guard cell. Such features of stomata have been efficiently used to identify the several polyploid citrus species (Abou Elyazid \& El-Shereif 2014; Wu \& Mooney 2002; Zeng et al. 2006). This procedure of polyploidy detection is usually rapid and simple. Nevertheless, they are often inaccurate and confirmation such as chromosome counting and nuclear genome size measurement by flow cytometry is usually required. The citrus triploids derived from the autotetraploid pollen parents through interploid hybridizations exhibited some informative phenotypic characters. In such crosses, Recupero et al. (2005) noted that the characteristics of the male parent generally dominated in the fruit phenotypes (size, color, quality, and appearance) of the triploid offspring. Un-developed seeds are found with considerably high frequencies of polyploids in several polyembryonic cultivars of Sweet orange and Tangor (Usman et al. 2006; Fatima et al. 2010). Oiyama \& Okudai (1986) reported that the leaves of tetraploid are broader, thicker, dark in colour, large size stomata, wider long petals, large calyxes, thicker pistils, ovaries at anthesis were longer as compared to their respective diploid (Barrett \& Hutchinson 1981; Grosser et al. 2014). The increased ploidy level exhibits increases cell size, thickness and leaf shape, which are less pointed from apex. Plants with more ploidy level have large flowers and fruits, thick branches and stems with shortened internodes and crotch angles (Sanford 1983), lower dry matter and higher water content in leaves (Jaskani et al. 2002; Bilquees et al. 2015). The diploid grow faster than triploid and tetraploid, as reported by Khan \& Rehman (1994). Fruit yield vary with selections that might have less economic but are important as breeding material (Khan \& Rehman 1994). However, only a low proportion of triploids produced satisfactory yield so far (Soost \& Cameron 1975). Tetraploids grow more slowly, compact in habit and yield less than diploids and triploid of the same cultivar (Khan \& Rehman 1994). According to Abou Elyazid \& El-Shereif (2014), generally the DNA content in the leaves tended to increase significantly by increasing the colchicine concentration and 
the time of exposure. The highest content $(207.1 \mu \mathrm{g} / \mathrm{ml})$ was recorded at the treatment of $0.2 \%$ colchicines for $24 \mathrm{~h}$ in leaves of $C$. reticulata. Other studies proved by colchicine treatment, the tetraploid cells contained DNA almost two times more than the diploid ones (Zeng et al. 2006; Wu \& Mooney 2002; Zhang et al. 2007).

The differences between the diploid and tetraploid differ in stomata dimensions also. The highest stomata length was found at $0.2 \%$ of colchicine for $12 \mathrm{~h}$, while the lowest ones were recorded under the control in mandarin (Abou Elyazid \& El-Shereif 2014). Highest stomata width recorded under $0.1 \%$ colchicines treatment for 12 and $48 \mathrm{~h}(128.3$ and $128.2 \mu \mathrm{m}$, respectively) followed by $0.2 \%$ for $12 \mathrm{~h}$. The control and $0.01 \%$ colchicines treatment for $24 \mathrm{hrs}$ showed the lowest value. As result of colchicine treatment on different citrus species and varieties, various anatomical changes such as large number of stomata with high density were reported in diploid citrus in comparison to tetraploids citrus where stomata were larger and spaced more widely (Oiyama \& Okudai 1986; Zeng et al. 2006; Wu \& Mooney 2002; Zhang et al. 2007; Wakana et al. 2005; Padoan et al. 2013).

\section{Rootstock and its importance in citrus}

In order to water stresses, plants have innate ability to develop several adaptive mechanisms at morphological, physiological, biochemical and molecular levels (Wang et al. 2003). As the morphological adaptive features, development of root system is most prominent to exhibit stress tolerance. Root system respond to water depleting conditions in the soil and send the signals to the leaves where closure of the stomata occurs to reduce water losses from the aerial part (GomezCadenas et al. 1996; Rodriguez-Gamir et al. 2010). In this context, rootstocks system in the citrus is the key consideration for responding to stress conditions. The commercial cultivation of citrus usually consists of two joined components (rootstock and scion) in budded or grafted plants (Maynard \& Bassuk 1990). Rootstock provides root system or below ground portion to plant and scion which provide the part of above ground on which flowering and fruiting takes place. For planning of a new orchard, due care is needed on various aspects like selection of suitable crop, variety, rootstock, planting distance, watering, nutritions etc. for successful citriculture. Among them, selection of appropriate rootstocks for various purposes viz. true-to-type, dwarfing, graft compatibility, tolerant to various biotic and abiotic stresses are crucial and play pivotal role in citriculture (Hartmann \& Kester 1959). This consideration is important as the rootstock has a major bearing on tree performance and fruit characteristics. Hitherto, rootstocks influence every aspects of tree and fruit development in citrus.

\section{Polyploidy rootstock in citrus}

The rootstocks have prominent effect on growth, productivity, fruit quality and longevity of the orchard on the one hand and influence the susceptibility of the trees to various insect-pest and diseases on the other hand. Polyploidization events often seem to be associated with increase in vigor and adaptation of the newly formed plant to novel conditions. The other applications of polyploidy are use in mutation breeding, production of seedless fruit, bridge crossing 
and industrial applications viz. increase in secondary as well as primary metabolites, such as antimalarial sesquiterpene, artemisin, artemisin etc. (Levin 1983) have been enhanced up to six-fold inducing by tetraploids compared to diploid plant (De Jesus-Gonzalez \& Weathers 2003). Some important cultivars have been evolved by ploidy manipulation (Spiegel-Roy 1988). Polyploid plants also have lower growth rates which can be used to induce dwarfing and tend to flower later or over a longer period to its respective diploids, which is also a desirable feature for increasing harvesting duration (Levin 2002). Such superior features exhibited by polyploid individuals have led to an increased interest to develop more polyploids for application in crop improvement programs. Triploids obtained from citrus breeding were found to be most resistant to low temperature. Similarly, tetraploids grow more slowly, compact in habit and produce lesser yield than diploids of the same cultivar; however, it can be used to induce dwarfing in the citrus plants (Khan \& Rehman 1994). In addition, autopolyploidy may positively affect the tolerance level of plants to stresses like nutrient deficiency, water deficit, drought, temperature, insectpests and pathogens (Levin 2002). Moreover, autopolyploids are also expected to have higher levels of heterozygosity compared to their related diploids due to polysomic inheritance and the possibility of out crossing occurrence (Osborn et al. 2003). Allopolyploids frequently display superior vigor in comparison to their two progenitors. Such hybrid vigor, also referred to as heterosis, generally points to increases in biomass, stature, growth rate, fertility levels and stress tolerance of the plants, and has been considered one of the most important aspects for crop improvement (Chen 2010; Van de Peer et al. (2017). A good citrus rootstock should have high degree of polyembryony, compatibility with the scion, adaptability to particular soil, tolerance to cold, salt, drought and wind, viruses especially tristeza, exocortis and ring spot, fungal diseases, nematodes etc. Citrus tetraploid seedlings were shown to be more tolerant to salt stress than their respective diploid parents (Podda et al. 2013).

Polyploid rootstocks in citrus and their applications

A single rootstock is not effectively suitable for all kind varieties, soil and climatic conditions. Thus, many polyploid rootstocks have been developed and characterized for various traits in recent past which are described below.

\section{Rangpur lime (C. limonia Osbeck)}

The diploid Rangpur lime is producing good vigor and fruit yield but fruit quality is medium. It has deep root system, resistance to tristeza, medium tolerance to root rot but showing susceptibility to exocortis and nematodes. It was extensively used in citrus for tolerant to salt and drought stress as rootstocks (Chadha \& Singh 1990; Nimbolkar et al. 2016). However, the citrus industries are continuously going to decline due to various biotic and abiotic stresses. To overcome these problems, the ploidy level in Rangpur lime has been increased as tetraploid and studied against these stresses. As doubling of the genome and changes in plant physiology and anatomy due to polyploidization, the stress tolerance ability of plants have enhanced 
significantly. When Kinnow mandarin was grafted on tetraploid rootstocks of Rangpur lime, it has possessed more tolerant to chromium (Cr-) toxicity as compare to diploid counterpart. The study suggested that $\mathrm{Cr}$ - was sequestrated from root to leaves and consequently avoiding oxidative damage to the plant (Balal et al. 2017). Similarly, Sweet orange cv.Valencia showed tolerant to drought stress on tetraploid Rangpur lime rootstock. A network of differentially expressed drought responsive proteins in valencia orange were identified when it was grafted on diploid and tetraploid rootstocks (Dutra de Souza et al. 2017). Cr- toxicity affects the biomass and growth in Kinnow mandarin used as scion on Rangpur lime (Balal et al. 2017). It was observed that 25 per cent and 47 per cent biomass were reduced in tetraploid and its diploid respectively, under $\mathrm{Cr}$ - stress. Similarly, the plant height was also reduced 11 per cent in tetraploid and 19 per cent in diploid Rangpur lime (Balal et al. 2017; Lopez- Luna et al. 2016; Adrees et al. 2015). Thus, it is suggested that the uptake of $\mathrm{Cr}$ ions was less in scion grafted on tetraploid rootstocks.

In another study, the ABA biosynthetic gene (CsNCED1) was up-regulated in tetraploid rootstocks as compare to control (diploid rootstocks) under drought stress conditions (Allario et al. 2013). Polyploidization in citrus particularly in rootstocks alter the accumulation of volatile organic compounds (VOC) and membrane stability in $C$. limonia leaves under water deficit conditions (Viera et al. 2016). Due to water deficit stress, the higher accumulation of VOC was recorded in tetraploid Rangpur lime.
The net photosynthetic rate and stomatal conductance were reduced in water stressed leaves whereas; Malondialdehyde (MDA) concentration was significantly increased in diploid leaves than to its tetraploid. It was also validated by expression analysis of $H P L$ and $D R E B 2 A$ gene under water deficit conditions which showed up-regulation accordance with stress conditions (Viera et al. 2016). Thus, it is suggested that tetraploids are showing more tolerance to stress.

\section{Alemow (C. macrophylla)}

Scion cultivars with Alemow (Citrus macrophylla Wester) have shown excellent horticultural performance with decreased impact of biotic and soil problems (MedinaUrrutia 1996). The seedlings of tetraploid Alemow showed more tolerant to salt stress than its diploid counterpart. Moderate salinity reduces the biomass in $4 \mathrm{x}$ plants as compare to its $2 \mathrm{x}$ plants. This is the consequence of the reduced ability of tetraploid seedling for $\mathrm{Cl}^{-}$ uptake by the root and subsequently transport to the shoot. It has been reported that the uptake of $\mathrm{Cl}^{-}$by root and translocation to the leaves are related to the water absorption and transpiration respectively (Syvertsen et al. 2010). In addition to this, potassium concentration in plant tissue drops as the sodium concentrations is increased which resulting into ions imbalance and hence plants become susceptible to nutrient stress. But in case of tetraploid Alemow, the uptake of $\mathrm{K}^{+}$ ion is higher than $\mathrm{Na}^{+}$ion as a result it showed salinity tolerance compared to its diploid plants (Grattan \& Grieve 1992; Chao et al. 2013; Martinez-Alcantara et al. 2015). The tetraploid Alemow plants show a higher capacity of $\mathrm{Cl}^{-}$exclusion, probably led by 
reduced transpiration rate that delays the salt stress-induced leaf damage (Ruiz et al. 2016). These attributes of Alemow $(4 x)$ plants in stressed condition is due to doubling of the genome and alteration in plant physiology and anatomy (Ruiz et al. 2016).

\section{Trifoliata orange (Poncirus trifoliate)}

Trifoliate orange is originally a citrus relative comes under Rutaceae family and by nature; it is sole triploid rootstock of citrus. It is an excellent rootstock source for cold hardiness, resistant to foot rot, tristeza virus and nematode (Hutchhison 1985). Several hybrids of Trifoliata orange are valuable rootstocks so it has been used extensively in citrus improvement programs (Grosser 1988). It is reported that tetraploid Poncirus trifoliata was more tolerant to salinity than their respective diploid counterpart. This tolerant character of rootstocks is because of less accumulation of $\mathrm{Cl}^{-}$and $\mathrm{Na}^{+}$in their aerial part. It is suggested that tetraploid rootstocks have specific root anatomy that limit the uptake of these toxic ions (Saleh et al. 2008; Ruiz et al. 2016; Balal et al. 2017). It is reported that autotetraploid rootstocks cause lower fruit yield with inferior quality like thick and irregular albedo (Jacquemond \& Rocca Serra, 1992; Hussian et al. 2011). To overcome this statement, Hussian et al. (2012) has concluded that autotetraploidy in Trifoliata orange rootstocks do not impact on quality of fruits of Clementine cultivar; however, it reduces fruit yield and modify the rootstocks/scion physiology like photosynthetic rate, stomatal conductance and electron transport rate. Trifoliata orange as tetraploid rootstock showed dwarfing character as compared to its triploid counterpart. Thus, the per unit area yield of fruit will be higher because of increased number of plant population.

\section{Carrizo citrange}

Diploid Carrizo citrange is resistance to cold, foot rot and tristeza but susceptible to but scaling. This rootstock also exhibit poor absorption of micronutrient especially in calcareous soil (Martínez-Cuenca et al. 2013). Tetraploid Carrizo citrange was developed by crossing between $C$. sinensis L. and Poncirus trifoliata and subsequently by doubling of the ploidy in the F1 generation (Oustric et al. 2017). The tetraploid Carrizo citrange showed more drought stress tolerant than its diploid counterpart due to thicker roots and less surface exchange with the soil thus, probably it consumes less water (Oliveira et al. 2017). In general, the ABA synthesis is directly correlated with drought tolerance in plants (Agusti et al. 2007; Allario et al. 2013). Similarly, the higher expression of ABA biosynthetic genes (ABI1 and NCED3) were reported in Carrizo citrange $(4 \mathrm{x})$ plants (Merlot et al. 2001; Agusthi et al. 2007, Oliveira et al. 2017) However, in tetraploid Carrizo citrange the expression of $\mathrm{ABA}$ in roots was not correlated with its ability to withstand against drought stress. The better tolerance to water deficit conditions was showed due to higher expression of CAT2 gene in the leaves which may participate the scavenging of $\mathrm{H}_{2} \mathrm{O}_{2}$ content (Oliveira et al. 2017). Regarding salinity tolerance in Carrizo citrange, the tetraploid plants enhanced the ability to exclude chloride from the leaves which leads to the salinity tolerance (Saleh et al. 2008; Ruiz et al. 2016). It is reported that the uptake of $\mathrm{Cl}^{-}$by the roots and translocation 
to the shoot is higher (1.4-fold) in diploid plants than tetraploid during salt treatments which resulted into 1.6-fold higher $\mathrm{Cl}^{-}$ accumulation in the leaves of diploid plants. As the consequent, tetraploid plants produced less-branched roots with lower number of root tip and 1.7-fold higher root length as well as net $\mathrm{Co}_{2}$ assimilation (1.5-fold) was also higher in tetraploid than its diploid plants. Moreover, leaf damage was much higher in diploid in term of burnt area (8-fold) and defoliation (6fold) as compared to tetraploid plants. It is also reported that salinity stress significantly reduced in dry matter content $(37 \%)$ in diploid but did not impact on tetraploid plants (Syvertsen \& Garcia-Sanchez 2014; Ruiz et al. 2016).

Boron is one of the most essential micronutrients required for growth and development of plants. It participated into formation of cell wall structure, root elongation, carbohydrate metabolism, phenol accumulation etc. (Herrera-Rodriguez et al. 2010; Funakawa \& Miwa 2015). However, citrus is very sensitive to boron excess whose toxicity caused various physiological disorder ultimately that leads to reduce plant vigor and yield (Grattan et al. 2015; Martinez-Cuenca et al. 2015). The rootstocks of tetraploid Carrizo citrange prevent the citrus tree from damages caused by boron in excess. The tetraploids exhibits tolerance to stress caused by boron excess. This attribute in $4 \mathrm{x}$ rootstocks is due to root anatomical modifications induced by the genome duplication (Ruiz et al. 2016). In citrus, rootstocks are used to improve fruit production and quality, and improve the tolerance to abiotic stresses including chilling stress. When Clementine was grafted on tetraploid Carrizo citrange rootstocks, the natural chilling stress tolerance in scion was reported by Oustric et al. (2017). During the excess chilling stress, Clementine on rootstock $(\mathrm{C} / 4 \mathrm{xCC})$ showed decrease in physiological and biochemical attributes like photosynthetic rate, stomatal conductance, chlorophyll content and starch and MDA level as compared to its diploid $(\mathrm{C} / 2 \mathrm{xCC})$. Specific enzymatic activities such as ascorbate peroxidase (APX), catalase (CAT) and dehydroascorbate reductase (DHAR) were higher in $\mathrm{C} / 4 \mathrm{xCC}$ during the cold stress period. Contrarily, chlorophyll, proline, ascorbate and $\mathrm{H}_{2} \mathrm{O}_{2}$ levels and SOD activity not significantly altered between $\mathrm{C} / 4 \mathrm{xCC}$ and C/2xCC (Oustric et al. 2017).

\section{Flhorag 1 (FL1)}

Flhorag 1 is an allotetraploid (4x) somatic intergeneric hybrid of [Willow Leaf Mandarin (C. paradisi-4x) + Pomyroy Poncirus (Poncirus trifoliata-4x). Recently, it is being used as rootstocks in citriculture at the region where chilling and high light intensity stress) occurred. FL-1(4x) exhibits enhanced chilling and light stress tolerance as compare to its parents of diploid and their respective double diploids (Oustric et al. 2018). It is suggested that greater antioxidant capability in FL-1 should make this allotetraploid hybrid more tolerant to chilling stress than the two WLM genotypes, and light stress than the two WLM and POP genotypes. During the cold and light stress, low photoinhibition and less accumulation of oxidative stresses were observed in FL-1 4x plants than diploid and doubled-diploid genotypes.

Cleopatra Mandarin (C. reshni Hort. ex Tan) 
The plants grafted on Cleopatra rootstocks (2x) were demonstrated higher tolerance to salt and drought, and it is a well-known chloride excluder (Cerda et al. 1979); however, it is susceptible to nematodes (Chadha \& Singh 1990). Fruit shows low levels of albedo breakdown (Treeby et al. 1995) and low susceptibility to decay under storage (Ritenour et al. 2004), but it shows high levels of weight loss during storage period (Alirezanezhad \& Eamin 2006; Machado et al. 2015). This rootstock is very much suitable for virgin soils (Hardy, 2004). The tetraploid rootstock of Cleopatra seems to be potential source to overcome these problems in its quality, storage and cultivation. Regarding growth parameters of scion on $C$. reshmi tetraploid and its diploid rootstocks, the significant difference in leaf, stem and root dry mass were reported under Cr- toxic conditions. Similarly, plants grafted on $2 \mathrm{x}$ and $4 \mathrm{x}$ did not show any significant differences in total chlorophyll concentration and leaf gas exchange parameters under $0 \mathrm{mM}$ $\mathrm{Cr}$ - treatment. However, plant grafted on $4 \mathrm{x}$ under higher concentration of $\mathrm{Cr}$ - exhibited higher chlorophyll concentration than their respective diploid rootstocks (Balal et al. 2017). The accumulation pattern of $\mathrm{Cr}$ differed in the leaves and roots due to polyploidization in citrus rootstocks (Oliveira 2011). It is reported that roots of tetraploid Cleopatra accumulating more concentration of $\mathrm{Cr}$ - than the roots of its diploid without any observable deformities in the root growth. Interestingly, grafted plants on $4 x$ Cleopatra showed $\mathrm{Cr}$ - tolerance because it is restricted at root level and thus not translocating to the leaves (Balal et al. 2017). The higher accumulation of $\mathrm{Cr}$ - reported the antagonistic effect on acquisition of essential nutrients for plants (Dube et al. 2003). However, this antagonistic effect of Cr- did not showed any alteration in tetraploid roots growth and acquisition of nutrients in the leaves of scion (Balal et al. 2017). In case of citrus, the antioxidant system is very prominent to avoid oxidative stress in saline conditions (Arbona et al. 2003). But higher accumulation of $\mathrm{Cr}$ damaged the antioxidant system in plants grafted on $2 x$ rootstocks than $4 x$ rootstocks (Dixit et al. 2002; Adrees et al. 2015; Balal et al. 2017). The plant growth rate of diploid Cleopatra mandarin is even normal during the salt stress but in case of tetraploid Cleopatra, the tolerance level against salt stress is much higher (Saleh et al. 2008).

Fepagro C 13 and C 37 (C. sinensis cv. Para $X P$. trifoliata)

The prominent leaf characteristics of Fepagro C-13 and C-37 are trifoliate type because of the characters governed by a dominant gene donated by $P$. trifoliata (Saunt 1990). The tetraploid plants presented more leathery leaves with intense green colour than its diploid plants (Guerra et al. 2014). The consequences of leaf colour and texture are directly correlated with increasing of photosynthetic enzyme and cell pigmentation (Leech et al. 1985). Besides changes in physiological attributes, the morphological variations like petiole length, leaf length, and size of leaves are noted in tetraploid and diploid genotypes. Low plant height $(30.0 \mathrm{~cm})$ was recorded in tetraploid as compared to its diploid counterpart $(41.5 \mathrm{~cm})$ thus plant is exhibiting dwarfing character (Guerra et al. 2014). Based on these characteristics, it can be 
suggested that Fepagro $\mathrm{C} \quad 13$ and $\mathrm{C} 37$ tetraploid plant could be more tolerant to stresses which need to be evaluated in the future.

\section{Conclusion}

The rootstock is a key component of successful and sustainable citrus orchard. Development of genetically uniform and superior rootstock is an important task in citrus. In citrus, a lot of species and hybrids are being used as rootstocks for various purposes and objectives. A single rootstock is not effectively suitable for testing all the scions under different soil and climatic conditions. In citrus, diploid rootstocks have been utilized since past time, even though, these rootstock are suffering to a lot of biotic and abiotic stresses throughout citriculture in the world. The diploid rootstocks are vigorous in nature thus grafted plants on it acquire giant shape after 10-13 years. To maintain size and shape in such circumstances, the growers have to start severe pruning. However, citrus plants do not like severe training and pruning as it resulted into decline due to contamination of various biotic factors and prone to abiotic stresses. As the consequence, the cost of cultivation is affected adversely and citrus growers are getting heavy loss. To address these problems, polyploids have been selected throughout evolution because of their genome plasticity leading to selective advantages over diploid, and in most cases an enhanced vigor. Adaptation of polyploid populations to novel environments was evaluated and the evolutionary consequences of exposure to these environments were analyzed. Among these polyploids rootstock, tetraploid rootstocks are found more tolerance to biotic and abiotic stress during evaluations. Numerous tetraploid somatic hybrids have been produced by protoplast fusion for rootstock breeding. The findings suggested that increased tolerance in tetraploid rootstocks could be related to more effective regulation of the transpiration stream and that it is related to increased ABA synthesis in root among rootstocks. The tetraploid rootstocks have highly responded to drought, salinity, chilling, nutrient and heavy metals stresses than their diploid parents. However, allotetraploid are found more superior than autotetraploid regarding multi-stresses because they are produced from two differently superior autotetraploids. Thus, allotetraploids can be recommended to establish citrus orchards where environmental problems occurred more. All developed polyploid rootstocks of citrus need to be evaluated comparatively as future study so that most superior rootstocks can be identify among them.

\section{References}

Abou Elyazid DM \& El-Shereif AR. 2014. In vitro induction of polyploidy in Citrus reticulata Blanco. Am J Plant Sci, 5:16791685.

Acosta-Motos JR, Ortuno MF, Bernal-Vicente A, Diaz-Vivancos P, Sanchez-Blanco MJ \& Hernandez JA. 2017. Plant responses to salt stress: Adaptive mechanisms. Agron, $7: 18$

Adrees M, Shafaqat A, Muhammad I, Saima $\mathrm{AB}$, Zeenat S, Mujahid F, Qasim A, Rashid S \& Muhammad R. 2015. Mannitol alleviates chromium toxicity in wheat plants in relation to growth, yield, stimulation of anti-oxidative enzymes, oxidative stress and $\mathrm{Cr}$ uptake in sand and 
soil media. Ecotoxicol Environ Saf, 122:1-8.

Agust J, Zapater M, Iglesias DJ, Cerco M, Tadeo FR and Talo M. 2007. Differential expression of putative 9-cisepoxycarotenoid dioxygenases and abscisic acid accumulation in water stressed vegetative and reproductive tissues of citrus. Plant Sci, 172:85-94.

Ahlawat YS. 1997. Viruses, greening bacterium and viroids associated with citrus (Citrus species) decline in India. $J$. Agric Sci, 67: 51-57.

Aleza P, Juarez J, Cuenca J, Ollitrault P \& Navarro L. 2010. Recovery of citrus triploid hybrids by embryo rescue and flow cytometry from $2 x \quad 3 \quad 2 x$ sexual hybridisation and its application to extensive breeding programs. Plant Cell Rep, 29:1023-1034.

Alirezanezhad A \& Eamin, AA. 2006. Effect of eight citrus rootstocks on storage life of grapefruit cultivars Marsh and Ruby Red. Iranian Journal of Agricultural Sciences, 37: 447-455.

Allario T, Brumos J, Comenero-Flores JM, Iglesias DJ, Pina JA, Navarro L, Talon M, Ollitrault P and Morillon R. 2013. Tetraploid Rangpur lime rootstock increases drought tolerance via enhanced constitutive root abscisic acid production. Plant Cell Environ, 36:856-868.

Carvalho SA \& Silva LFC. 2013. Monitoring the viability of citrus rootstocks seeds stored under refrigeration. Revista Brasileria de Fruticultura, 35: 238-245.

Arbona V, Flors V, Jacas J, Garcia-Agustin P, Gómez-Cadenas A \& Gomez-Cadenas A. 2003. Enzymatic and non-enzymatic antioxidant responses of Carrizo citrange, a salt-sensitive citrus rootstock, to different levels of salinity. Plant Cell and Physiology, 44:388-394.
Balal RM, Shahid MA, Vincent C, Zotarelli L, Liu G, Mattson NS, Rathinasabapathi B, Martínez-Nicolas JJ \& Garcia-Sanchez F. 2017. Kinnow mandarin plants grafted on tetraploid rootstocks are more tolerant to Cr-toxicity than those grafted on its diploids one. Environ Exp Bot, 140: 8-18.

Bar-Joseph M \& Dawson WO. 2008. Citrus tristeza virus. Encyclopedia of Virology, 1: 520-525.

Barrett H C and Huthinson D J (1978) Spontaneous tetraploidy in apomictic seedlings of citrus. Econ Bot, 32:27-45.

Bilquees F, Usman M, Khan MS, Khan IA \& Khan MM. 2015. Identification of citrus polyploids using chromosome counts, morphological and SSR markers. Pak $J$ Agric Sci, 52:107-114.

Biswas KK, Tarafdar A, Sharma SK, Singh JK, Dwivedi S, Biswas K \& Jayakumar BK. 2014. Current status of citrus tristeza virus incidence and its spatial distribution in citrus growing geographical zones of India. Indian J Agric Sci, 84:184-189.

Byadgi AS \& Ahlawat YS. 1995. A new viral ring-spot disease of citrus (Citrus species) in India. Indian J Agric Sci, 65: 763-770.

Byrt S, Munns R, Burton RA, Gilliham M \& Wege S. 2018. Root, cell wall solutions for crop plants in saline soil caitlins. Plant Sci, 269:47-55.

Cameron JW \& Burnett RH. 1978. Use of sexual tetraploid seed parents for production of triploid citrus hybrids. Hort Science, 13:167-169.

CCRI, 2015. www.ccringp.org.in

Chadha KL \& Singh HP. 1990. Proc. citriculture scenario of India. Abohar, Punjab, 21-64.

Chen ZJ. 2010. Molecular mechanisms of polyploidy and hybrid vigor. Trends Plant Sci, 15:57-71. 
Comai L 2005. The advantages and disadvantages of being polyploid. Nat Rev Genet, 6: 836-846.

Cuenca J, Aleza P, Navarro L \& Ollitrault P. 2013. Assignment of SNP allelic configuration in polyploids using competitive allele-specific PCR: Application to citrus triploid progeny. Ann bot., 111: 731-742.

De Jesus-Gonzalez L \& Weathers P. 2003. Tetraploid Artemisia annua hairy roots produce more artemisinin than diploids. Plant Cell Rep 2: 809-813.

Dixit V, Pandey V \& Shyam R. 2002. Chromium ions inactivate electron transport and enhance superoxide generation in vivo in pea (Pisum sativum cv. Azad) root mitochondria L. Plant Cell Environ, 25: 687-693.

Dube BK, Tewari K, Chatterjee J \& Chatterjee C. 2003. Excess chromium alters uptake and translocation of certain nutrients in Citrullus. Chemosphere, 53:1147-1153.

Economos C \& Clay WD. 1998. The twelfth session of the intergovernmental group on citrus fruit, 22-25 September 1998, Valencia, Spain.

Fan J, Chen C, Achor DS, Brlansky RH, Li ZG \& Gmitter FGJ. 2013. Differential anatomical responses of tolerant and susceptible citrus species to the infection of Candidatus Liberibacterasiaticus. Physiol Mol Plant Pathol, 83: 69-74.

Fatima B, Usman M, Khan IA, Khan MS \& Khan MM. 2010. Exploring citrus cultivars for underdeveloped and shriveled seeds: a value able source for spontaneous polyploidy. Pak J Bot, 42: 189-200.

Flexas J, Ortuno MF \& Ribas-Carbo M. 2007. Mesophyll conductance to $\mathrm{CO}_{2}$ in Arabidopsis thaliana. New Phytol, 175: 501-511.

Frank WM. 1998. Entomology Circular No. 180. Florida Department of Agriculture and Consumer Services, Division of Plant Industry. Originally published as FDACS/DPI.

Frost HB \& Soost RK. 1968. Seed reproduction: development of gametes and embryos, in: Reuther, W., Batchelor, L.D., Webber, H.J. (Eds.), The citrus industry. Vol 2, University of California Press, Berkeley, pp. 290-324.

Funakawa H and Miwa K (2015) Synthesis of borate cross-linked rhamnogalacturonan II. Front. Plant Sci, 6: 223-233.

Ghosh DK, Bhose S, Mukherjee K \& Baranwal VK. 2018. Sequence and evolutionary analysis of ribosomal DNA from Huanglongbing (HLB) isolates of western India. Phytoparasitica, 4: 295305

Gomez HD. 2008. Experience on HLB (Huanglongbing) symptoms detection in Florida. Experience on HLB symptoms detection, Hermosillo, Sonora, México

Gomez-Cadenas A, Tadeo FR, Talon M \& Primo-Millo E. 1996. Leaf abscission induced by ethylene in water-stressed intact seedlings of Cleopatra mandarin requires previous abscisic acid accumulation in roots. Plant Physiol, 112: 401-408

Gora JS, Kumara R, Sharma BD, Ram C, Berwal MK, Singh D, Bana RS \& Kumar P. 2022. Performance evaluation of Fremont mandarin on different rootstocks under the hot arid environment of India. South African Journal of Botany, 142 (3): 124-133.

Gora JS, Kumar R, Ram C, Berwal MK \& Haldhar, SM. 2021. Citrus decline and its management in arid region. In book: Current Horticulture: Improvement, Production, Plant Health Management and Value-Addition. Publisher: Brillion Publishing. Chapter 21, 269-279.

Gora JS, Kumar R, Rram C, Berwal MK, Bhat, V, Kumari L \& Parihar D. 2019. Role of Rootstocks for Quality Production in Fruits Crops. In book: "Hi-tech approaches for production and value 
addition of horticultural crops in arid and semiarid regions"Publisher: SKRAU. Pp. 112-125.

Graca JV. 1991. Citrus greening disease. Annu Rev Phytopathol, 29: 109-136.

Graham JH \& Johnson EG, 2013. Presymptomatic fibrous root decline in citrus trees caused by Huanglongbing and potential interaction with Phytophthora spp., Plant Disease, 97: 1195-1199.

Grosser JW \& Gmitter FGJ. 2013. Breeding disease-resistant citrus for Florida: adjusting to the canker/HLB world - part 2: rootstocks. Citrus Industry

Grosser JW, Gmitter FG \& Chandler JL. 1988. Intergeneric somatic hybrid plants of Citrus sinensis cv. Hamlin and Poncirus $\quad$ trifoliata cv. Flying Dragon. Plant Cell Rep, 7: 5.

Grosser JW, Kainth D \&Dutt M. 2014. Production of colchicine-induced autotetraploids in pummelo (Citrus grandis Osbeck) through indirect organogenesis. Hort Science, 49: 944-948

Guerra D, Wittmann MSW, Schwarz SF, Dutra de Souza PV, Gonzatto MP \& Weiler RL. 2014. Comparison between diploid and tetraploid citrus rootstocks: morphological characterization and growth evaluation. Bragan. Camp 73: 1-7

Guerra D, Wittmann MTS, Schwarz SF, Weiler RL, Dahmer N \& Paulo Vitor de Souza D. 2016. Tetraploidization in citrus rootstocks: effect of genetic constitution and environment in chromosome duplication. Crop Breed Appl Biotechnol, 16:35-41.

Hardy S. 2004. Growing Lemons in Australia - A Production Manual. New South Wales, Australia

Hartmann HT \& Kester DE. 1959. Plant Propagation: Principles and Practices, second ed. Prentice-Hall, New Jersey

Hutchison DJ. 1985. Rootstock development screening and selection for disease tolerance and horticultural characteristics. Fruit Var. J, 39:21-25.

Jaskani MJ, Khan MM \& Khan IA. 2002. Growth, morphology and fruit comparison of diploid and tetraploid Kinnow mandarin. Pak J Agric Sci, 39: 126-128.

Jiao Y, Wickett NJ \& Ayyampalayam S. 2011. Ancestral polyploidy in seed plants and angiosperms. Nature, 473: 97-100.

Johnson EG, Wu J, Bright DB \& Graham JH. 2014. Association of Candidatus Liberibacterasiaticus root infection, but not phloem plugging with root loss on huanglongbing-affected trees prior to appearance of foliar symptoms. Plant Pathology, 63: 290-298.

Kainth D \& Grosser JW. 2010. Induction of autotetraploids in pummelo (Citrus grandis L. Osbeck) through colchicine treatment of meristematically active seeds in vitro. Proceeding of the Florida State Horticultural Society, 123: 44-48.

Khan MD \& Rehman H. 1994. Crop improvement in horticulture, in: Bashir, E., Bantel, R. (Eds.), Horticulture. Islamabad, National Book Foundation, pp. 150-152

Kim JS, Sagaram US, Burns JK, Li JL \& Wang N. 2009. Response of sweet orange (Citrus sinensis) to "Candidatus Liberibacter asiaticus" infection: microscopy and microarray analyses. Phytopathology, 99: 50-57.

Koh EJ, Zhou L, Williams DS, Park J, Ding N, Duan YP \& Kang BH. 2012. Callose deposition in the phloem plasmodesmata and inhibition of phloem transport in citrus leaves infected with "Candidatus Liberibacterasiaticus". Protoplasma, 249: 687-697.

Lakshm TN, Gopi V, Gouri Sankar T, Sarada G, Lakshmi L, Ramana K T V and Gopal K. 2014. Status of diseases in Sweet orange and acid lime orchards in Andhra 
Pradesh, India. Int J Curr Microbiol Appl Sci, 3: 513-518.

Lee LS. 1989. Citrus polyploidy origins and potential for cultivar improvement. Australian Journal of Agricultural Research 4:735-747

Leech RM, Leese BM \& Jellings AJ. 1985. Variation in cellular ribulose-1, 5bisphospahte-carboxylase content in leaves of Triticum genotypes at tree levels of ploidy. Planta, 166: 259-263.

Levin DA. 1983. Polyploidy and novelty in flowering plants. The American Naturalist, 122: $1-25$.

Levin DA. 2002. The role of chromosomal change in plant evolution. Systematic Botany, 29: 460-461.

Lin KH. 1956. Observations on yellow shoot on citrus. Etiological studies of yellow shoot on citrus. Acta Phys Sin, 2: 237-242.

Machado FLDC, da Costa JDP, Teixeira AD S and Da Costa JMC. 2015. The influence of rootstock and time of harvest on hte fruit quality during storage of in two grapefruit cultivars. Acta Sci Agron, 37: 341-346.

Martinez-Cuenca MR, Forner-Giner MÁ, Iglesias DJ, Primo-Millo E \& Legaz F. 2013. Strategy I responses to $\mathrm{Fe}-$ deficiency of two citrus rootstocks differing in their tolerance to iron chlorosis. Sci Hortic, 153: 56-63.

Maynard BK \& Bassuk NL. 1990. Comparisons of stock plant etiolation with traditional propagation methods. The Combined Proceedings' of International Plant Propagators Society, 40: 517-23.

Merlot S, Gosti F, Guerrier D, Vavasseur A and Giraudat J. 2001. The ABI1 and ABI2 protein phosphatases $2 \mathrm{C}$ act in a negative feedback regulatory loop of the abscisic acid signaling pathway. Plant Journal, 25: 295-303.
Moreno P \& Garnsey SM. 2010. Citrus tristeza diseases $-A$ worldwide perspective In: Karasev AV and Hilf ME (eds.), citrus tristeza virus complex and tristeza diseases, APS Press, St. Paul, MN, 27-49

Nimbolkar PK, Awachare C, Reddy YTN, Chander S \& Hussain F. 2016. Role of rootstocks in fruit production-A review. $J$ Agric Eng Food Technol, 3:183-188.

Oiyama I \& Kobayashi S. 1990. Polyembryony in undeveloped monoembryonic diploid seeds crossed with a citrus tetraploid. Hortic Sci, 25: 12761277.

Oiyama I \& Okudai N. 1986. Production of colchicine induced autopolyploidy through micro grafting in mono embryonic citrus cultivars. Pak J Bot, 42: 189-200.

Oiyama I, Okudai N \& Takahara T. 1981. Ploidy levels of seedlings obtained from $2 \times 4$ crosses in citrus. Proceedings of the International Society of Citriculture, 1:3234.

Oliveira TM, Cidade LC, Gesteira AS, Coelho Filho MA, Soares Filho WS \& Costa MGC. 2011. Analysis of the NAC transcription factor gene family in citrus reveals a novel member involved in multiple abiotic stress responses. Tree Genet Genomes, 7:1123-1134.

Oliveira TM, Yahmed JB, Dutra J, Maserti BE, Talon M, Navarro L, Ollitraut P, Gesteira A \& Morillon R. 2017.Better tolerance to water deficit in doubled diploid 'Carrizo citrange' compared to diploid seedlings is associated with more limited water consumption. Acta Physiol Plant, 39: 204.

Osborn TC, Chris Pires J, Birchler JA, Auger DL, Jeffery Chen Z, Lee HS, Comai L, Madlung A, Doerge R \& Colot V. 2003. Understanding mechanisms of novel gene expression in polyploids. Trends Genet, 19:141-147. 
Otto SP \& Whitton J. 2000. Polyploid incidence and evolution. Ann Rev Genet, 34: 401-437.

Oustric J, Morillon R, Ollitrault P, Herbette S, Luro F, Tur I, Dambier D, Giannettini J, Berti L, Santini J \& Froelicher Y. 2018. Somatic hybridization between diploid Poncirus and citrus improves natural chilling and light stress tolerances compared with equivalent doubled-diploid genotypes. Trees, 32: 883-895.

Oustric J, Morillon R, Luro F, Herbette S, Lourkisti R, Giannettini J, Berti L \& Santini J. 2017. Tetraploid Carrizo citrange rootstock (Citrus sinensis L. Osb. Poncirus trifoliata L. Raf.) enhances natural chilling stress tolerance of common clementine (Citrus clementina Hort. ex Tan). J Plant Physiol, 214: 108115.

Padoan D, Mossad A, Chiancone B, Germana MA \& Khan PSAV. 2013. Ploidy level in Citrus clementine affects leaf morphology, stomatal density and water content. Theor Exp Plant Physiol, 25:283-290.

Perez-Perez JG, Robles JM \& Botia P. 2009. Influence of deficit irrigation in phase III of fruit growth on fruit quality in "Lane late" sweet orange. Agric Water Manag, 96: 969-979.

Podda A, Checcucci G, Mouhaya W, Centeno D, Rofidal V, Carratore RD, Luro FS, Morillon R, Ollitrault P \& Maserti BE, 2013. Salt-stress induced changes in the leaf proteome of diploid and tetraploid mandarins with contrasting $\mathrm{Na}+$ and $\mathrm{Cl}-$ accumulation behaviorJ. Plant Physiol, 170:1101-1112.

Ramsey J \& Ramsey TS. 2014. Ecological studies of polyploidy in the 100 years following its discovery. Philosophical Transactions of the Royal Society B, 369: e20130352.
Recupero RG, Russo G \& Recupero S. 2005. New promising citrus triploid hybrids selected from crosses between monoembryonic diploid female and tetraploid male parents. Hort Science, 40:516-520.

Ritenour MA, Dou H, Bowman KD, Boman B J, Stover E \& Castle WS. 2004. Effect of rootstock on stem-end rind breakdown and decay of fresh citrus. Hort Technology, 14: 315-319.

Rocha-Pena MA, Lee RF, Lastra R, Niblet CL, Ochoa-Corona FM \& Garnsey SM. 1995. Citrus tristeza virus and its vector Toxoptera citricida. Plant Disease, 79: 437-444.

Rodriguez-Gamir, Diego S, Intrigliolo PrimoMillo E \& Forner-Giner MA. 2010. Relationships between xylem anatomy, root hydraulic conductivity, leaf/root ratio and transpiration in citrus trees on different rootstocks. Physiol Plant, 139: 159-169/

Ruiz M, Quinones A, Martinez-Alcantara B, Aleza P, Morillon R, Navarro L, PrimoMillo E and Martínez-Cuenca MR. 2016. Tetraploidy enhances boron-excess tolerance in Carrizo citrange (Citrus sinensis L. Osb. $\mathrm{x}$ Poncirus trifoliata L. Raf.). Front Plant Sci., 7: 701.

Ruiz M, Quinones A, Martinez-Cuenca MR, Aleza P, Morillon R, Navarro L, PrimoMillo E \& Martinez-Alcantara B. 2016. Tetraploidy enhances the ability to exclude chloride from leaves in Carrizo citrange seedlings. J. Plant Physiol, 205: 1-10.

Saleh B, Allario T, Dambier D, Ollitrault P \& Morillon R. 2008. Tetraploid citrus rootstocks are more tolerant to salt stress than diploid. C R Biol, 331: 703-710.

Sanford JC. 1983. Ploidy Manipulations, in: Janik, J.N., (Eds.), Advances in Fruit Breeding. Purdue University Press, West Lafayelle, pp 100-123 
Saunt J. 1990. Citrus varieties of the world: An illustrated guide. Norwick, Sinclair International

Scora RW. 1975. On the History and Origin of Citrus. Bulletin of the Torrey Botanical Club, 102: 369-375.

Shokrollah H, Abdullah TL, Sijam K \& Abdullah SA. 2011. Potential use of selected citrus rootstocks and interstocks against HLB disease in Malaysia. Crop Protection, 30: 521-525.

Soltis PS \& Soltis DE. 2009. The role of hybridization in plant speciation. Аnnu Rev Plant Biol, 60: 561-588.

Soost RK \& Cameron JW. 1975. Citrus, in: Moore, J.N. and Janick, J. (Eds.), Advances in Fruit Breeding. West Lafayette, Indiana, Purdue University Press, pp 507-540

Spiegel-Roy P. 1988. Citrus breeding past, present and future, in: 6th International Citrus Congress, Middle East, 1, 9-17.

Storey R \& Walker RR. 1998. Citrus and salinity. Sci Hortic, 78: 39-81.

Tayale A \& Parisod C. 2013. Natural pathways to polyploidy in plants and consequences for genome reorganization. Cytogenet Genome Res, 140: 79-96.

Treeby MT, Storey R \& Bevington KB. 1995. Rootstock, seasonal and fruit size influences on the incidence and severity of albedo breakdown in Bellamy navel oranges. Aust J Exp Agric, 35:103-108.

USDA. $2014 . \quad$ http://www.nass.usda. gov/Statistics_by_State/Florida/

Publications/Citrus/fcs/201213/fcs1213.pd $\mathrm{f}$

Usman M, Saeed T, Khan MM \& Fatima B. 2006. Occurrence of spontaneous polyploids in citrus. Hort Science, 33: 124-129.

Van de Peer Y, Mizrachi E \& Marchal K. 2017. The evolutionary significance of polyploidy. Nat Rev Genet, 18:411-424.

Wakana A, Hanada N, Park SM, Fukudome I \& Kajiwara K. 2005. Production of tetraploid forms of acid citrus cultivars by top grafting of shoots with sprouting axillary buds treated with colchicine. Journal of Faculty of Agriculture Kyushu University, 50: 93-102.

Wang W, Vinocur B \& Altman A. 2003. Plant responses to drought, salinity and extreme temperature towards genetic engineering for stress tolerance. Planta, 218: 1-14.

Webber HJ \& Batchelor LD. 1948. The Citrus Industry, Vol. I. History, Botany and Breeding. Berkeley, University of California Press

Wu HW \& Mooney P. 2002. Autotetraploid Tangor plant regeneration from in vitro citrus somatic embryogenic callus treated with colchicine. Plant Cell Tissue Organ Cult, 70:99-104.

Zekri M \& Rouse RE. 2016. Citrus problems in the home landscape. Horticultural Science Department, UF/IFAS Extension

Zeng HZ, Chen CW, Hong L, Liu JH \& Deng XX. 2006. In vitro induction, regeneration and analysis of autotetraploids derived from protoplasts and callus treated with colchicine in citrus. Plant Cell Tissue Organ Cult, 87: 85-93.

Zhang J, Zhang M \& Deng X. 2007. Obtaining autotetraploids in vitro at a high frequency in Citrus sinensis. Plant Cell Tissue Organ Cult, 89: 211-216. 